\title{
Spiritual leadership, job Satisfaction, and its effect on organizational commitment and organiza-
} tional citizenship behavior

\author{
Abdul Kodir Djaelani ${ }^{a}$, Anwar Sanusi ${ }^{b}$ and Boge Trianmanto ${ }^{b^{*}}$
}

${ }^{a}$ Faculty of Economic and Business, Islamic University of Malang, East Java, Indonesia

${ }^{b}$ Post Graduate Program, University of Merdeka Malang, Indonesia

C H R O N I C L E

Article history:

Received: June 30, 2020

Received in revised format:

June 302020

Accepted: July 12, 2020

Available online:

July 20, 2020

Keywords:

Spiritual Leadership

Job Satisfaction

Organizational Commitment

Organizational Citizenship Behav-

ior

\section{A B S T R A C T}

Organizational citizenship behavior (OCB) has received a great deal of attention among researchers recently given the practical importance and its implication for the organizations. Building on a theoretical framework that links characteristics of leader and perception of individuals and their work settings to organizational commitment (OC) and citizenship behavior, the objective of this study was to investigate the relationship between spiritual leadership, job attitudes, and organizational citizenship behavior among lecturers at Islamic University. A cross-sectional design was used to meet the objectives set. Data were collected through the administration of questionnaires to 170 lecturers from Islamic University in Malang. Data were collected through 5 questionnaires in which participants completed measures of spiritual leadership, job satisfaction, organizational commitment, and OCBs. Results showed that one of the seven hypotheses proposed was rejected in this study. The results of structural equation modeling indicated a direct effect between spiritual leadership and OCB, and an indirect effect of organizational commitment on the relationship between spiritual leadership and job satisfaction toward OCB. The implications of these findings, as well as directions for future research, are addressed.

\section{Introduction}

Organizational Citizenship Behavior (OCB) has become a well-known concept and widespread component of organizational literature in recent Decades (Podsakoff, Mackenzie, Paine, \& Bachrach, 2000). The term OCB was first conceived by Bateman and Organ (1983), in which described as 'individual behavior that is discretionary, not directly or explicitly recognized by the formal reward system, and in the aggregate promotes the efficient and effective functioning of the organization' (Organ, 1988, p. 8). OCB is gained the most attention and focused area in the management and organization literature, with such many definitions, conceptualizations, determinants, and outcomes of this phenomenon in the workplace. One of common definition that OCB is: "Individual behavior that is discretionary, not directly or explicitly recognized by the formal reward system, and in the aggregate promotes the efficient and effective functioning of the organization" (Organ, Podsakoff, \& MacKenzie, 2006, pg. 3). Furthermore, OCB benefits the working efficacy of the organization and might not be recognized through the institution's payment methods. As a form of extra-role behavior, OCB is a major construct that has often been examined in the concepts of psychology and management over the past two decades (Shafazawana et al., 2016; Harun et al., 2020). A meta-analysis indicated (Podskoff, Podskoff, Whiting, Blume, 2009), that OCBs have significant relationships with a variety of individual-and organizational-level outcomes. Several previous researchers (Bateman \& Organ, 1983; Organ \& Ryan, 1995; Podsakoff et al., 2000) explained the main characteristic of OCB is the voluntary contribution of individuals to the organization by exceeding assignments according to job descriptions. For several reasons, OCB can affect organizational effectiveness and increase managerial productivity, coworkers, and streamlining the use of organizational resources to lead to 
productive goals (Podsakoff, et al., 2000). Organizations intending to achieve higher and more competitive performance essentially need to have individuals who could go beyond the call of their formal duty or job description and indulge themselves in discretionary behaviors like OCB. The success of an educational institution is significantly dependent on its willing teachers willingly doing the above expectations in their role in the organization (Di Paola \& Tschannen-Moran, 2001). This is why OCB behavior gets great attention on the type of teacher work and one's career in learning activities (Bogler \& Somech, 2004). In universities, teaching and learning are highly complex and challenging task as compared to teaching at schools because of the low formalization of teaching and learning content and methods in universities.

In an emerging "knowledge economy" higher education serves as an imperative for the economic and social development of a state. The success of the education system depends on the involvement, efforts, and contribution of academic staff or professional expertise (Noordin \& Jusoff 2009). In many universities, people are focusing on the dual-core functions of knowledge creation and knowledge transmission through research and teaching processes (Eyupoglu, 2016). The reality and changes in higher education not only affect the image and status of academic careers but also contribute to problems such as increased job dissatisfaction and job stress and decreased commitment to the institution (Pienaar \& Bester, 2006). The associations among leadership, satisfaction, commitment, and organizational citizenship behavior have been found by different researchers but among these variables, spiritual leaders have not been modeled and tested together regularly. The researchers with their previous empirical findings determined that job attitudes and leadership behaviors appear to have the most consistently positive relationships with commitment (Ali et al., 2014; Yahaya \& Ibrahim, 2016; Mouloud, Bougherra, dan Samir, 2016) and OCBs (Zeinabadi, 2010; Swaminathan \& Jawahar, 2013; Shafazawana et al., 2016). However, more research is needed on the relationship between spiritual leadership and organizational citizenship behavior (OCB).

Previous studies have suggested a positive association between leadership and Organizational Citizenship Behavior (OCB). Both citizenship behavior and job attitudes mechanisms have been studied in different and various professional groups. But the general view that citizenship behavior and job attitudes are significant in building organizational and individual goals in the specific context of higher education institutions (Chughtai \& Zafar, 2006; Triatmanto et al., 2019; Hartinah et al., 2020). Under such conditions, lecturers' OCB becomes very important to achieve academic results for student learning. The willingness of lecturers to engage in OCB behavior will affect learning outcomes for most of their students. According to Khalid et al. (2010), "The willingness of lecturers to exert greater effort through altruism, for example, helps students to understand difficult material; good manners, for example, giving advance notice of class delays, virtue voluntarily attending student activities; accuracy such as the efficient use of time allocated for lectures and tutorials; and sportsmanship, for example, avoiding complaints when dealing with non-compliant students can be expected to improve student academic achievement". This would imply the importance of studying lecturers OCB in a higher education institution.

The purpose of this quantitative study was to determine the effects of spiritual leadership and job satisfaction on organizational commitment and organizational citizenship behavior among lecturers working in Islamic University located in Malang, province of East Java, Indonesia. Another significant aspect of this study is that studying lecturers OCB at Islamic University would add evidence to the existing body of knowledge from a emerging knowedge in developing university. Indonesia is a developing country, and Malang is the city that developing in East Java province and the importance of higher education for the development of a country needs no reference. The results of the study are of high value to leaders and administrators of Islamic university to know spiritual leadership and job attitude that instill and uphold organizational commitment but also organizational citizenship behavior among university lecturers.

\section{Literature Review and Hypotheses Development}

Ferguson and Miliman (2008) argued about the concept of spirituality in leadership has a critical implication, with Fry (2003) in his causal model explaining that spiritual leadership can foster organizational results in which one of them is increasing individuals' commitment and productivity. Some of the previous studies imply that job satisfaction is closely related to employee attitudes toward work. The higher level of job satisfaction will be reflected in a work attitude towards a more positive direction. Conversely, job dissatisfaction will lead to negative work attitudes. Positive and negative work attitudes of a person will follow the level of perceived job satisfaction. The level of job satisfaction possessed will affect an individual's commitment to his organization. Chen and Yang (2012) in their research examine the relationship between spiritual leadership (vision, hope, and altruistic love) with OCB (altruism and conscientiousness), which is mediated by spiritual resilience. Furthermore, it makes it easier for individuals in the organization to perform excellent organizational citizenship behavior, including altruism to help colleagues and responsibilities for the organization. This shows the importance of a leader's role in encouraging extra-role behavior among individuals in the organization. This research shows that leaders who develop an effective vision can give individuals a sense of calling and find meaning in life and create a different life. The process to develop a visionary form of Chen and Yang's altruistic values (2012). Through hopes and beliefs in a leader's vision, individuals in the organization are encouraged to achieve more challenging goals. Spiritual leadership facilitates employees' spiritual feelings by helping them feel more meaningful in their work and greater citizenship feelings for the organization. These would ultimately increase the OCB of employees. Spiritual leadership in educational institutions has been reviewed by Kaya (2015) in his research reviewing the spiritual leadership model and its influence on the OCB dimension according to the perception of 383 teachers from elementary schools. In general, spiritual leadership can predict the four dimensions of 
OCB, especially virtue in OCB. This is understandable because spiritual leadership greatly contributes to forming a more solid foundation for OCB in an organization, including in educational institutions. Nasiri (2015) explains that 224 administrative staff from 470 Iranian universities, revealed that organizational citizenship behavior can be positively influenced by organizational commitment. This finding shows that the higher quality of organizational commitment results in employee's OCB. Affective organizational commitment shows that administrators identify with the organization, feel happy because they are members of the organization, and are committed strongly and voluntarily to the organization, and show the alignment of organizational and administrator values. In this study, an integrative framework is proposed that can show the relationship between the four main concepts: spiritual leadership, job satisfaction, organizational commitment, and OCB. Based on the theories and empirical results that have been presented in the previous section, the conceptual framework proposed in this study can be seen in the following figure:

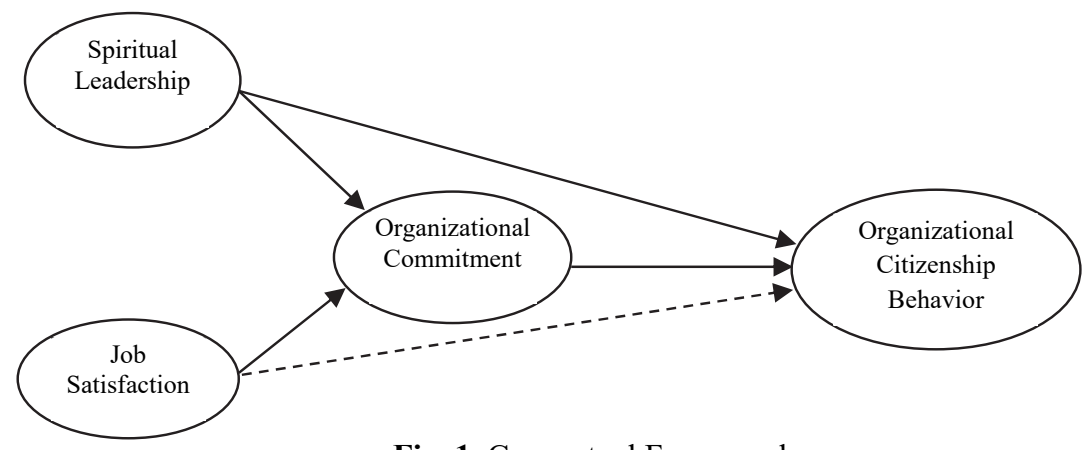

Fig. 1. Conceptual Framework

The concepts and constructs related to the variables of interest, their relationships, and the population under investigation need to be defined. The variables of interest represent multidimensional constructs, so each dimension of these constructs is explained. The theoretical underpinnings and conceptual framework for the relationship between spiritual leadership, job satisfaction, organizational commitment, and OCB are also clarified. The conceptual framework of the study shows that there is a direct relationship between spiritual leadership (Chen \& Yang, 2012; Ali et al., 2014; Kaya, 2015; Sudibjo \& Sutarji, 2020), and job satisfaction (Mouloud, et al., 2016; Shafazawana et al., 2016; Tung \& Ly, 2020) with OCB. As a form of extrarole behavior in individual performance, OCB could be seen as a behavioral outcome from leadership patterns and the extent of an individual's satisfaction with their work. In addition to spiritual leadership and job satisfaction, individuals' feeling of bound with their organizations could also contribute positively to OCB. The individual who is more committed to his organization will tend to show more positive work results, such as OCB. To note that both job satisfaction and organizational commitment have become key forms of attitude for individuals in their work. Then job satisfaction is also recognized as the most important antecedent of organizational commitment, in the sense that to be more emotionally and psychologically bound to the organization, the individual must be able to feel satisfied with job-related factors in his work. The relationship between satisfaction and commitment has been widely studied and explored in previous empirical results (Altinoz et al., 2012; Mouloud et al., 2016; Dwi et al., 2020). Some empirical results show inconsistencies in measurement as well as in the coefficient of the relationship or its effect. To investigate the direct relationship among variables which this study addressed, certain research hypotheses had to be tested. Therefore, the following hypothesis is proposed:

H1. Spiritual leadership will have a positive and significant effect on lecturers' organizational commitment.

H2. Job satisfaction will have a positive and significant effect on lecturers' organizational commitment.

H3. Spiritual leadership will have a positive and significant effect on lecturers' OCB.

H4. Job satisfaction will have a positive and significant effect on lecturers' OCB.

H5. Organizational commitment will have a positive and significant effect on lecturers' OCB.

The relationship of both forms of spiritual leadership and job satisfaction with individual outcomes like extra-role behaviors has been proposed by various researchers, some suggesting more of those variables would be accounted for organizational commitment. In this research context, such power may make lecturers at Islamic University feel that their efforts in the academic institution are valued and recognize their challenging work. Leader recognition, on the one hand, promotes employees' confidence in their abilities, which further stimulates them to believe that they are capable of completing their assigned tasks. On the other hand, lecturers' job attitudes could be more beneficial to build emotional bonding and psychological attachment to the organization while this also can fostering their extra-role behavior. Specifically, the hypotheses in the current study are proposed below: 
H6. There is a significant mediating role of organizational commitment on the effect of spiritual leadership on lecturers' organizational citizenship behavior.

H7. There is a significant mediating role of organizational commitment on the effect of job satisfaction on lecturers' organizational citizenship behavior.

\section{Method}

A non-experimental design and quantitative methodology were applied in this study. Quantitative data were collected, and the 7 hypotheses had to be tested, so quantitative methods were the most proper and practical approach for this study. This quantitative research was based on positivist, postpositivist, and pragmatic paradigms regarding the nature of reality as objective, certain, and thus quantifiable. Given the stage of research on spiritual leadership and job satisfaction and its relationship with commitment and OCB, a quantitative methodology was an appropriate approach to reach an understanding of workplace phenomenon around these concepts. Specifically, this study examined the relationship between spiritual leadership, job satisfaction, and organizational citizenship behavior. Spiritual leadership and job satisfaction was a predictor variable, and OCB was an outcome variable. Therefore, this study investigated whether this relationship was entirely or partially mediated by organizational commitment. To gather quantitative data, convenience sampling, and questionnairebased, cross-sectional surveying was used. In the present study, all the questionnaires were adapted from existing measures. Lecturers responded to spiritual leadership, job satisfaction, organizational commitment, and OCB questionnaires. All of the self-administered questionnaires were completed by respondents during separate faculty meetings with lecturers. Spiritual leadership was measured by a scale developed by Fry (2003) dan Fry, Vitucci, dan Cedillo (2005). This scale has three subscales (vision, hope/faith, altruistic love) and 17 items. Job satisfaction was measured by a scale developed by Hulin dan Judge (2003). This scale has five subscales (pay, opportunities for promotion, coworkers, supervision, the job itself), and 15 items. Organizational commitment was measured by a scale developed by Allen and Mayer (1990,1993). This scale has three subscales (affective commitment, continuance commitment, normative commitment), and 9 items. Organizational citizenship behavior was measured by a scale developed by podsakoff (2000). This scale has a five subscale (civic virtue, sportsmanship, courtesy, conscientiousness, altruism) and 15 items. At the time of data collection, there were 2 private and well-known Islamic universities located in Malang as the object of this study. The population was 342 lecturers from both of them. In this context, the target population is full-time or permanent lecturers who work in the universities. In the quantitative phase, surveys were sent to 170 full-time faculty lecturers, the list of which was retrieved from the official administrator of the universities. They were approached through key contact persons or via e-mails and invited to complete the questionnaire. Data were analyzed at both the individual levels. Structural equation modeling was used to investigate hypotheses and other relationships that emerged during analysis. Also, factor loading scores of the retained items were statistically significant, and the result of the CFA is summarized in Table 1.

Table 1

Mean, Standard Deviation and Factor Loading

\begin{tabular}{llll}
\hline & Mean & SD & Factor Loadings \\
\hline Spiritual Leadership & & & 0.888 \\
Vision & 4.018 & 0.763 & 0.918 \\
Hope / Faith & 4.042 & 0.751 & 0.823 \\
Altruistic Love & 3.827 & 0.778 & 0.785 \\
Job Satisfaction & & & 0.781 \\
Pay Satisfaction & 3.84 & 0.852 & 0.795 \\
Satisfaction toward promotion & 3.72 & 0.831 & 0.923 \\
Satisfaction toward coworker & 3.84 & 0.839 & 0.807 \\
Satisfaction toward supervisor & 3.92 & 0.809 & \\
Satisfaction toward job itself & 3.98 & 0.800 & 0.866 \\
Organizational Commitment & & & \\
Affective Commitment & 4.12 & 0.774 & 0.892 \\
Continuance Commitment & 3.90 & 0.857 & 0.854 \\
Normative Commitment & 4.06 & 0.778 & \\
Organizational Citizenship Behavior & & & 0.765 \\
Conscientiousness & 3.89 & 0.839 & 0.795 \\
Altruism & 3.87 & 0.809 & 0.790 \\
Civic Virtue & 4.02 & 0.737 & 0.688 \\
Sportmanship & 4.04 & 0.735 & 0.740 \\
\hline
\end{tabular}




\section{Result and Discussion}

Descriptive statistics were conducted to report the means score, standard deviations, and factor loading of the spiritual leadership, job satisfaction, organizational commitment, and organizational citizenship behavior. Tables 1 presents the means, standard deviations, and factor loadings. The impressive discriminant validities as seen in each factor loadings among these construct (spiritual leadership, job satisfaction, organizational commitment, and OCB) measures demonstrate that a good fit in constructs validity. Table 2 shows that initial correlation tests revealed several promising relationships that prompted further investigation. Many of these relationships were significant at the .01 probability level, demonstrate a significant relationship to all predictor of OCB (spiritual leadership, job satisfaction, and organizational commitment) and OCB itself. Alpha Cronbach of all constructs was varied from $0.820-883$. These results are consistent with major previous findings, which showed good internal consistency among constructs.

Table 2

Descriptive Statistic and Intercorrelations

\begin{tabular}{lcccc}
\hline & $\mathbf{1}$ & $\mathbf{2}$ & $\mathbf{3}$ & $\mathbf{4}$ \\
\hline Spiritual Leadership & $\mathbf{( . 8 2 0 )}$ & & & \\
Job Satisfaction & $\mathbf{. 6 9 6 * *}$ & $\mathbf{( . 8 8 3 )}$ & & \\
Organizational Commitment & $\mathbf{. 6 7 0 * *}$ & $\mathbf{. 7 2 4 * *}$ & $\mathbf{( . 8 7 8 )}$ & $\mathbf{( . 8 2 4 )}$ \\
Organizational Citizenship Behavior & $\mathbf{. 6 7 3 * *}$ & $\mathbf{. 6 3 9 * *}$ & $\mathbf{. 7 6 4 * *}$ & 4.12 \\
Mean & $\mathbf{4 . 0 4}$ & 3.98 & 4.12 & .783 \\
Standard Deviation & $\mathbf{. 7 6 4}$ & .826 & .803 & 4
\end{tabular}

Notes: **p, $0.01 ; * \mathrm{p}, 0.05$; Cronbach's alphas for each scale are italicized and shown in the diagonal.

All correlations were significant. An overview suggests that data were consistent with previous studies. Spiritual leadership was positively related to job satisfaction $(r=0.696, p, 0.01)$, organizational commitment $(r=0.670, p, 0.01)$, and OCB $(r$ $=0.673, \mathrm{p}, 0.01)$. Job satisfaction was positively related to organizational commitment $(\mathrm{r}=0.724, \mathrm{p}, 0.01)$, and OCB $(\mathrm{r}=$ $0.639, \mathrm{p}, 0.01)$. In addition, organizational commitment was found to be positively related to OCB $(\mathrm{r}=0.764, \mathrm{p}, 0.01)$.

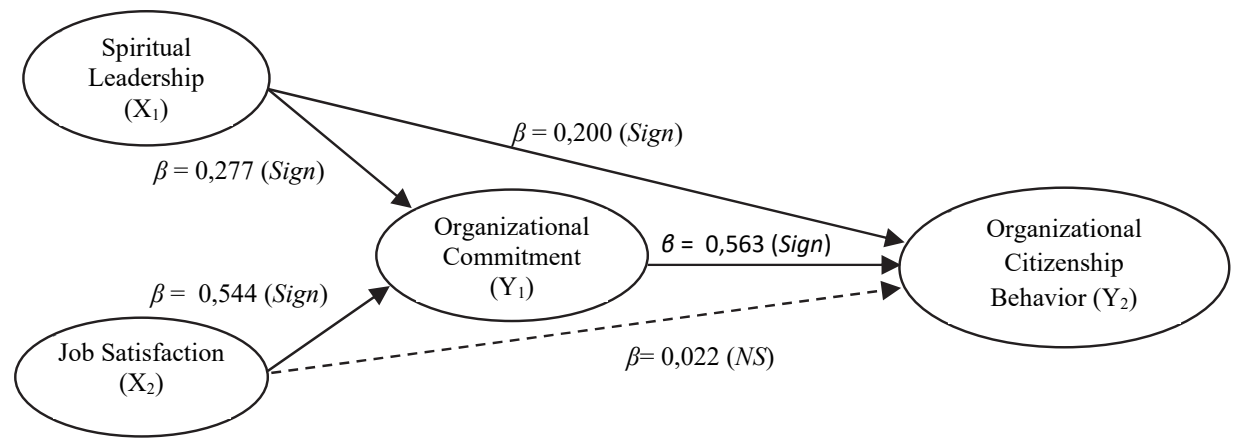

Fig. 2. The results of testing hypotheses

Fig. 2 displays the results of the analysis of the model proposed in this study. Standardized parameter estimates for the model are presented. The results suggest that spiritual leadership $(\beta=0.277, \mathrm{p}<0.05)$ and job satisfaction $(\beta=0.544, \mathrm{p}<0.01)$ significantly affect organizational commitment. Therefore, hypothesis 1 and 2 are accepted. Spiritual leadership $(\beta=0.200$, $\mathrm{p}<0.01)$, significantly affects organizational citizenship behavior, while job satisfaction $(\beta=0.022, \mathrm{p}>0.05)$ does not significantly affect OCB. Hypothesis 3 is accepted while hypothesis 4 is rejected. The results of this study are not in line with previous studies conducted such as Kim (2006) which reported that a higher level of individuals' job satisfaction would exhibit a higher level of OCB. Another possible explanation for the lack of effect between job satisfaction and OCB is related to the fact that the effect of satisfaction in the lecturers on OCB decreases in times of adversity context in Islamic Universities. This can be explained by two important characteristics of the Islamic high education system: the composition and the collectivist spirit of the Islamic community in a high educational system. The results suggest that organizational commitment $(\beta=0.563$, $\mathrm{p}<0.05$ ), significantly affects organizational citizenship behavior. Therefore, hypothesis 5 is accepted. Based on what has been cited, organizational commitment has a positive effect on organizational citizenship behavior. The more lecturers are committed to the university, the more organizational citizenship behavior is expected. To examined the mediating effects of organizational commitment on the effect of spiritual leadership and job satisfaction on OCB (Hypotheses 6 and7), two models were examined, a full and a partial mediation model. Based on Baron and Kenny's (1986) condition on mediation analysis, a positive linear relationship between spiritual leadership and job satisfaction as predictor variables and organizational commitment as a mediator variable, while OCB as an outcome variable. The model which tested in this study confirms that organizational commitment has an important mediating role in the relationship of spiritual leadership and job satisfaction on OCB. The result showed that the hypothesis 6 and 7 were confirmed. Results from the first mediation analysis also indicated a positive relationship between spiritual leadership and organizational commitment as well as a positive relationship between 
organizational commitment and OCB. Organizational commitment was a mediator of a relationship between spiritual leadership and OCB. Besides, results from the second mediation analysis showed a positive relationship between job satisfaction and organizational commitment as well as a positive relationship between organizational commitment and OCB. Organizational commitment was a mediator of a relationship between job satisfaction and OCB.

\section{Conclusion}

The findings in this study have revealed that the effects that emerge both from spiritual leadership and job satisfaction from lecturers can be transmitted through an organizational commitment to organizational citizenship behavior. More specifically the influence between spiritual leadership on organizational citizenship behavior is partially mediated by organizational commitment. On the other hand, organizational commitment has the role of perfect mediation on the influence between job satisfaction and OCB. The study has demonstrated the crucial importance of leadership and commitment in promoting OCBs in lecturers. Although scholars contend that job satisfaction can serve as a proximal antecedent of OCB, empirical findings regarding the relationship between different job satisfaction and OCB have been quite inconsistent in this study. As a central role played by commitment lecturers in higher education institutions should be taken into account seriously. This implies the understanding that human resources are the most important factor with the highest potential to make a difference, the importance of the latter in terms of universities leader to create a positive organizational context that fosters the development of high-quality education for Islamic Universities in Malang. In addition to reporting the research findings, it is important to outline some limitations of this study to identify ways to improve future research on the relationship between spirituality in the workplace with job attitudes and organizational citizenship behavior. First, a few other key variables have not been included in this study. Second, the organizational citizenship behavior of lecturers was rated by the self-assessment; it would have been better if the variable had also been measured by using the dean' rating, to avoid same-source bias. Third, the results of this study are bound by focusing on one institution.

The present findings have several implications for future research, some of which are related to the limitations of this study. Future studies should focus on the inclusion of these variables to have a more comprehensive understanding of the development of citizenship behavior among university lecturers. To establish the causal relationship among these variables with a high degree of confidence, longitudinal studies should be done. Expanding future research to include other various factors within research institutions as possible contributors to organizational commitment and OCB, such as university structures and hierarchy, organizational support, and culture, are some of the possible options for future exploration.

\section{Acknowledgement}

The authors of this article declare no conflict of interest. The authors are responsible for the content and writing of the paper.

\section{References}

Ali, N., Jan, S., Ali, A., Tariq, M. (2014). Transformational and transactional leadership as predictors of job satisfaction, commitment, perceived performance, and turnover Intention. Life Science Journal, 11, 48 - 53.

Allen, N. J., \& Meyer, J. P. (1990). The measurement and antecedents of affective, continuance, and normative commitment to the organization. Journal of Occupational Psychology, 63, 1-18.

Allen, N. J., \& Meyer, J. P. (1993). Organizational commitment: Evidence of career stage effects?. Journal of Business Research, 26, 49-61.

Altınöz, M., Çakıroğlu, D., \& Çöp, S. (2012). The effect of job satisfaction of the talented employees on organizational commitment: A field research. Procedia - Social and Behavioral Sciences, 58322 - 330.

Bateman, T. S., \& Organ, D. W. (1983). Job satisfaction and the good soldier: The relationship between affect and employee "Citizenship". Academy of Management Journal, 26(4), 587-595.

Bogler, R., \& Somech, A. (2004). Influence of teachers empowerment on teachers organizational citizenship behaviour in schools. Teaching and Teacher Education, 20(3), 277-289.

Chen, C.Y., \& Yang, C.F. (2012). The impact of spiritual leadership on organizational citizenship behavior: A multi-sample analysis. Journal of Business Ethics, 105, 107-114. DOI 10.1007/s10551-011-0953-3.

Chughtai, A.A., \& Zafar, S. (2006). Antecedents and consequences of organizational commitment among Pakistani university teachers. Applied H.R.M. Research, 11(1), 39-64.

Di Paola, M. F., \& Tschannen-Moran, M. (2001). Organizational Citizenship Behavior in Schools and its Relationship to School Climate. Journal of School Leadership, 11, 424-447.

Dwi, E., Astuti, W., \& Triatmanto, B. (2020). The role of service performance mediating the effect of management commitment to service quality structure on the reputation of hospitality industry companies in West Java. 10, $2869-2874$. https://doi.org/10.5267/j.msl.2020.4.021

Eyupoglu, S.Z. (2016). The organizational citizenship behaviour of academic staff in North Cyprus. Procedia Economics and Finance, 39, 701 - 704. DOI: 10.1016/S2212-5671(16)30280-5

Ferguson, J., \& Milliman, J. (2008). Creating effective core organizational values: A spiritual leadership approach. International Journal of Public Administration, 31(4), 439-459. 
Fry, L. W. (2003). Toward a theory of spiritual leadership. The Leadership Quarterly, 14, 693-727.

Fry, L. W. (2008). Spiritual Leadership: State-of-the-Art and Future Directions for Theory, Research, and Practice Spirituality in Business (editor Jerry Biberman dan Len Tischler).

Fry, L. W., \& Slocum, J. (2008). Maximizing the triple bottom line through spiritual leadership. Organizational Dynamics, 37, 86-96.

Fry, L. W., Vitucci, S., \& Cedillo, M. (2005). Spiritual leadership and army transformation: Theory, measurement, and stabling a baseline. The Leadership Quarterly, 16, 835-862.

Hartinah, S., Suharso, P., Umam, R., Syazali, M., Lestari, B., Roslina, R., \& Jermsittiparsert, K. (2020). Teacher's performance management: The role of principal's leadership, work environment and motivation in Tegal City, Indonesia. Management Science Letters, 10(1), 235-246.

Harun, N., Mahmood, N., \& Othman, S. (2020). The effect of talent management factors on teacher's leadership at the secondary schools. Management Science Letters, 10(1), 225-234.

Hulin, C. L., \& Judge, T. A. (2003). Job attitudes: A theoretical and empirical review. Dalam W. C. Borman, D. R. Ilgen, \& R. J. Klimoski (Eds.), Handbook of psychology (Vol. 12, pp. 255-276). Hoboken, NJ: Wiley.

Kaya, A. (2015). The relationship between spiritual leadership and organizational citizenship behaviors: A research on school principals' behaviors. Educational Sciences: Theory \& Practice, 15(3), 597 - 606.

Khalid, S.A., Jusoff, Hj.K., Othman, M., Ismail, M., \& Rahman, N.A. (2010). Organizational citizenship behavior as a predictor of student academic achievement. International Journal of Economics and Finance, 2(1), 65-71.

Mouloud, K., Bougherra, B., \& Samir, B. F. (2016). Job satisfaction for physical education teachers and its relationship to job performance and organizational commitment. Pedagogics, Psychology, Medical-biological Problems of Physical Training and Sports, 3, 47-51. DOI:10.15561/18189172.2016.0307.

Nasiri, M. (2015). The survey of conceptual modeling of causal relationship between organization commitment with organizational citizenship behavior in campus recreation administrations. International Journal of Sport Studies, 5(6), 653-658.

Noordin, F., Jusoff, K. (2009). Levels of job satisfaction amongst Malaysian academic staff. Asian Social Science, 5(5), 122128.

Organ, D. W. (1988). Organizational citizenship behavior: The good soldier syndrome. Lexington, MA: Lexington Books.

Organ, D. W., \& Ryan, K. (1995). A meta-analytic review of attitudinal and dispositional predictors of organizational citizenship behavior. Personnel Psychology, 48(4), 775-802.

Organ, D. W., Podsakoff, P. M., \& MacKenzie, S. B. (2006). Organizational citizenship behavior: Its nature, antecedents, and consequences. USA: Sage Publications, Inc.

Pienaar, C., Bester, C. (2006). Typical career dilemmas of academic staff during the early career phase within a changing South African higher education institution. South African Journal of Education, 26(4), 581 - 594.

Podsakoff, P. M., MacKenzie, S. B., Paine, J. B., \& Bachrach, D. G. (2000). Organizational citizenship behaviors: A critical review of the theoretical and empirical literature and suggestions for future research. Journal of Management, 26(3), 513563. DOI: 10.1177/014920630002600307.

Podsakoff, N. P., Whiting, S. W., Podsakoff, P. M., \& Blume, B. D. (2009). Individual- and organizational-level consequences of organizational citizenship behaviors: A meta-analysis. Journal of Applied Psychology, 94(1), 122-141.

Shafazawana, M.T., Ying, C.Y., Zuliawati, M.S., Sukumaran, K. (2016). Managing Job Attitudes: The Roles of Job Satisfaction and Organizational Commitment on Organizational Citizenship Behaviors. Procedia Economics and Finance, 35, 604 - 611. DOI: 10.1016/S2212-5671(16)00074-5.

Sudibjo, N., \& Sutarji, T. (2020). The roles of job satisfaction, well-being, and emotional intelligence in enhancing the teachers' employee engagements. Management Science Letters, 10(11), 2477-2482.

Swaminathan, S., \& Jawahar, P. D. (2013). Job satisfaction as a predictor of organizational citizenship behavior: An empirical study. Global Journal of Business Research, 7(1), 71-80.

Triatmanto, B., Wahyuni, N., \& Respati, H. (2019). Continual Human Resources Empowerment through Human Capital and Commitment for the Organizational Performance in Hospitality Industry. QUALITY Access to Success, $20(173), 84-91$.

Tung, N., \& Ly, L. (2020). Factors affecting literature learning behavior of secondary high school students: Evidence in Vietnam. Management Science Letters, 10(14), 3265-3270.

Yahaya, R., \& Ebrahim, F. (2016). Leadership styles and organizational commitment: a literature review. Journal of Management Development, 35(2), 190-216. https://doi.org/10.1108/JMD-01-2015-0004.

Zeinabadi, H., \& Salehi, K. (2011). Role of procedural justice, trust, job satisfaction, and organizational commitment in Organizational Citizenship Behavior (OCB) of teachers: Proposing a modified social exchange model. Procedia - Social and Behavioral Sciences, 29, 1472 - 1481. DOI: 10.1016j.sbspro.2011.11.387. 
(C) 2020 by the authors; licensee Growing Science, Canada. This is an open access article distributed under the terms and conditions of the Creative Commons Attribution (CC-BY) license (http://creativecommons.org/licenses/by/4.0/). 